\title{
Strategi Digital Marketing dan Komunikasi Bisnis untuk Enterpreneur Pemula di Indonesia
}

\author{
Lia Kurniawati $1^{*}$ \\ ${ }^{1}$ Politeknik Kridatama Bandung, Indonesia \\ *Korespondensi: liakurniawati2610@gmail.com
}

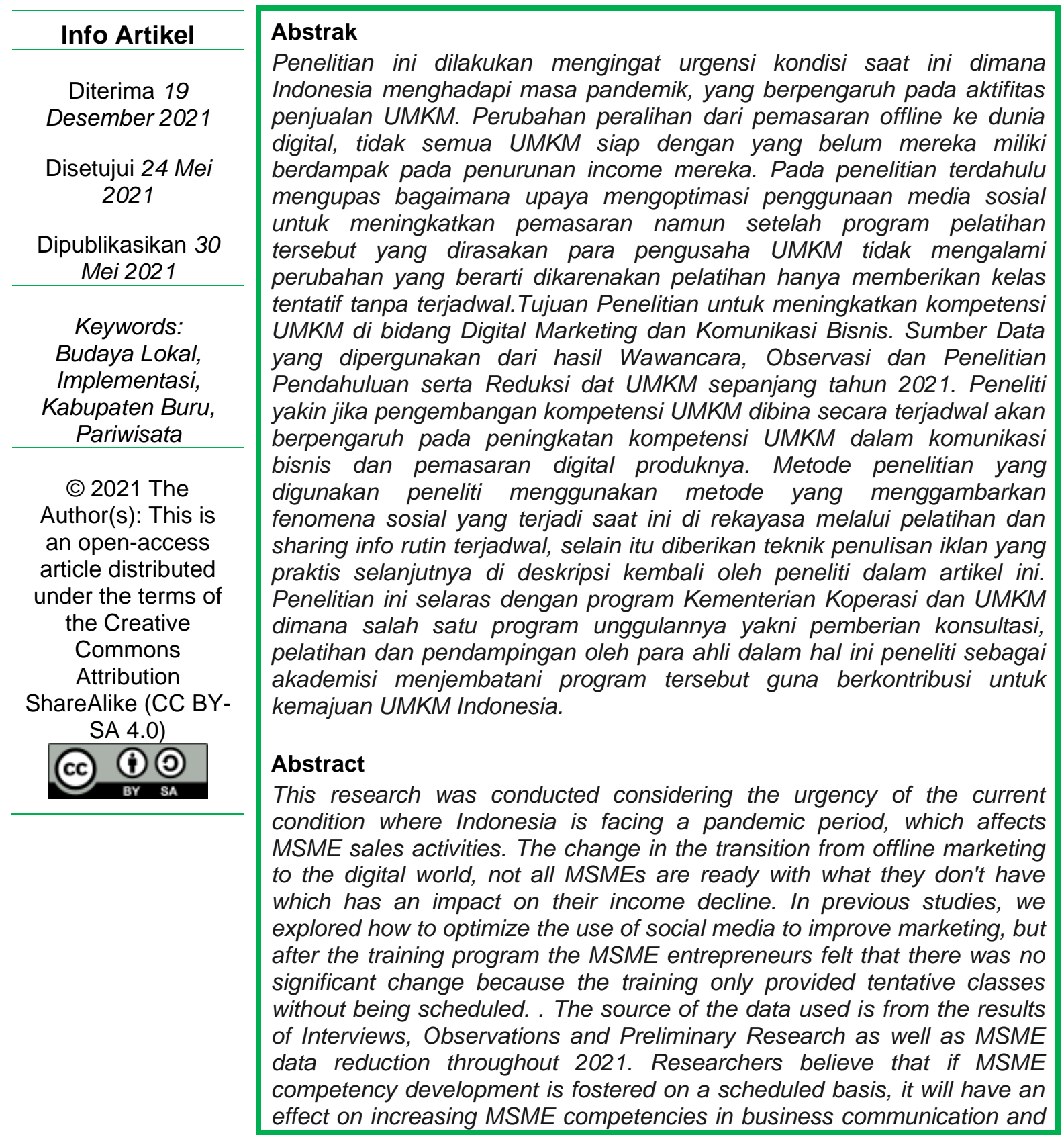


digital marketing of their products. The research method used by the researcher uses a method that describes social phenomena that are currently occurring in engineering through training and regularly scheduled information sharing, besides that, practical advertising writing techniques are then described again by the researchers in this article. This research is in line with the program of the Ministry of Cooperatives and MSMEs where one of the flagship programs is the provision of consultation, training and assistance by experts in this case researchers as academics bridge the program to contribute to the progress of Indonesian MSMEs.

\section{Pendahuluan}

Dengan melihat potensi internet memasuki tahun 2000an semua orang memanfaatkannya sebagai media sosialisasi dan penjualan online. Dengan hadirnya Kaskus, Olx dan platform penjualan online lainnya kurang lebih satu dekade terakhir perkembangan dunia online sangat pesat. Menurut data pengguna internet sampai dengan tahun 2021 ini mencapai 203 Juta Jiwa, pertumbuhannya sangat meningkat dari ketahun, seperti dari tahun sebelumnya pengguna internet naik sebesar $15.5 \%$ atau sebesar 27 juta jiwa.

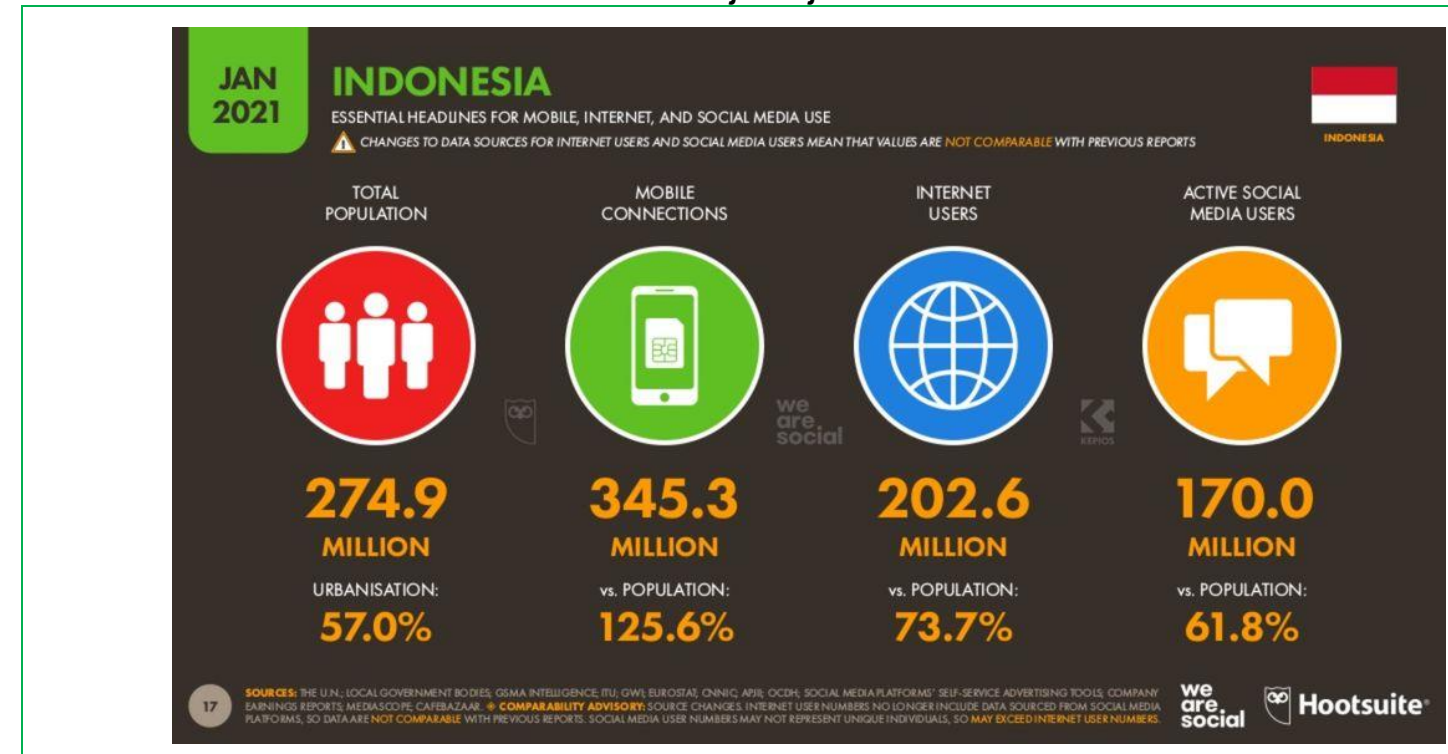

Gambar 1. Data pengguna internet dikutip dari https://inet.detik.com/

Melihat potensi angka tersebut sangat potensial penjualan melalui online jadi pilihan utama dibandingkan penjualan offline dan angka tersebut masih diprediksikan terus meningkat sampai tahun 2030 mendatang. Sehingga harapan mengais rezeki dari penjualan online sangat bisa di andalkan jika maintenance digital marketing konsisten terus menerus dilakukan.

Pada era digital produk bersaing bebas dengan memanfaatkan teknologi digital salah satunya adalah pemasaran digital (Online Marketing) adalah istilah umum untuk pemasaran produk atau jasa dengan menggunakan teknologi digital, terutama di Internet. Pemasaran digital dinilai efisien dan murah. (Wahyudi et al., 2019) 
Untuk menghadapi persaingan produk dari luar daerah maupun asing dibutuhkan kompetensi umkm dalam dunia digital marketing, baik untuk memasarkan maupun mengumpulkan data base calon pelanggan sesuai dengan minat dan targetnya. Digital marketing adalah kegiatan promosi dan pencarian pasar melalui mediadigital secara online dengan memanfaatkan berbagai sarana misalnya jejaring social (Sulaksono, 2020)

Jenis media sosial yang digunakan oleh subyek penelitian ini hampir sama dengan hasil penelitian di North West Manchester Inggris yang menggunakan Company blog/website, Facebook, Twitter, dan YouTube. cenderung lebih disukai karena kemudahannya dalam menarik perhatian dari target. Facebook dengan fungsi "like" dan kemudahan berinteraksi dengan komentar sebelumnya akan memberikan efek domino yang dapat memperkuat image dari produk. (Priambada, 2015)

Di era sekarang ini, para pelaku UMKM hendaknya bisa memanfaatkan media digital sebagai salah satu upaya pemasaran produknya sehingga konsumen lebih mengenal produk yang dihasilkan oleh UMKM tersebut.Perkembangan teknologi digital memungkinkan para pelaku UMKM untuk memasarkan produknya secara online dan melakukan transaksi melalui sistem perbankan secara online pula (Naimah et al., 2020)

Perkembangan UMKM yang memasuki masa pandemi peralihan dari pemasaran offline ke dunia digital, tidak semua UMKM siap dengan kompetensi yang serba baru menurut mereka, bahkan hal ini berdampak secara psikologis dengan imbasan pada penurunan perekonomian secara signifikan baik skala micro maupun skala nasional.

Pada penelitian terdahulu beberapa mengupas tentang bagaimana upaya mengoptimasi penggunaan media sosial untuk meningkatkan pemasaran namun setelah program pelatihan tersebut perubahan yang dirasakan para pengusaha di tingkat UMKM tidak mengalami perubahan yang berarti dikarenakan pelatihanpelatihan serupa hanya memberikan kelas-kelas tentatif tanpa bimbingan intensif yang terencana dan terjadwal.

Peneliti yakin jika pengembangan kompetensi UMKM dibina secara optimal, terencana dan terjadwal melalui kelas-kelas yang terjadwal syarat teknis akan membawa pengaruh pada optimalisasi penggunaan teknologi komunikasi bisnis dan digital serta peningkatan pemasaran UMKM. Guna mengoptimalkan potensi tersebut dibuat kelas-kelas online (strategi pemasaran, teknik penulisan iklan dan editing postingan), optimasi media sosial organic dan berbayar, ide postingan dan yang penting diantara semua hal adalah membuat para UMKM konsistensi melakukan semua hal itu.

Perkembangan teknologi digital memungkinkan para pelaku UKM untuk memasarkan produknya secara online dan melakukan transaksi melalui sistem perbankan secara online pula. Perkembangan teknologi digital telah mengubah pemasaran dari usaha kecil dan menengah (UKM) yang semula dilakukan secara konvensional menjadi secara digital dengan memanfaatkan penggunaan media sosial dan penggunaan website untuk memasarkan produk mereka. Pemanfaatan media online menjadi pilihan tepat bagi para UKM untuk mengembangkan bisnis yang dijalankannya. 
Mudahnya akses internet saat ini, besarnya manfaat yang didapatkan, serta murahnya biaya yang dibutuhkan menjadi alasan utama bagi UKM sebelum akhirnya mereka memilih media online sebagai solusi tepat untuk memperluas jangkauan bisnisnya (Wardhana, 2015)

Optimasi kompetensi UMKM dilakukan melalui pelatihan-pelatihan seperti pada penelitian sebelumnya, Usaha Mikro, Kecil dan Menengah (UMKM) mempunyai peran penting dan strategis dalam pembangunan ekonomi nasional. Selain berperan dalam pertumbuhan ekonomi dan penyerapan tenaga kerja, UMKM juga berperan dalam mendistribusikan hasil-hasil pembangunan (Hadiyati et al., 2018). Seperti yang dilakukan oleh peneliti yang bekerjasama dengan tim entrepreneur ID dari kegiatan pelatihanorganic dengan mengandalkan engagement ke kegiatan berupa Pelatihan Digital Marketing Dan Optimasi Seo pada beberapa media sosialseperti facebook, intagram dan whatsapp untuk membantu memaksimalkan pemasaran produk secara online.

Metode Pelatihan umkm yang digunakan pada kegiatan pembinaan kompetensi UMKM ini adalah metode kuliah whatsapp, diskusi dan tanya jawab yang disediakan di moment tertentu pada pelatihan daring melalui telegram, email dan live stream.

Pada penelitian terdahulu Peran Digital Marketing sebagai Upaya Peningkatan Omset. menyebutkan bahwa penentuan target market merupakan hal pertama yang harus dilakukan oleh UMKM karena hal ini akan berpengaruh pada traffic dan conversi yang akan di dapatkan ketika UMKM mulai merambah menggunakan komunikasi bisnis dan digital. Penentuan konsumen yang tepat dapat dilihat dari perilaku konsumennya. Tetapi untuk menentukan konsumen yang tepat adalah tidak mudah.

Sedangkan pada penelitian lainnya menyebutkan, terjadinya kesenjangan antara peserta pelatihan lebih banyak bertumpu pada pengalaman empiris selama mengelola usaha, sementara instruktur terkadang terjebak pada aspek teoritisnormatif. Kesenjangan tersebut muncul bukan terletak pada kualitas SDM yang rendah, melainkan lebih pada kurangnya pengetahuan tentang manfaat metode pemasaran yang berbasis teknologi informasi melalui mobile marketing whatsapp business.

Hal ini pengusaha juga menyadari bahwa mengelola usaha secara professional sangat diperlukan bagi peningkatan kinerja bisnis ditengah persaingan yang ketat. Mereka paham benar bahwa usaha yang mereka kelola menghadapi persaing yang ketat.Kondisi tersebut membutuhkan komunikasi yang lancar dengan mitra kerja agar proses transformasi pengetahuan dan ketrampilan berlangsung efektif (Hadiyati et al., 2018)

Dari penjelasan penelitian-penelitian terdahulu bahwa masih banyak hal-hal teknis di lapangan dalam upaya peningkatan kompetensi UMKM, terkendala penyampaian komunikasi, persamaan persepsi, pemahaman teknis pengenalan dunia komunikasi bisnis dan digital dan frekuensi pelatihan yang hanya sesekali tanpa retensi.

\section{Metode Penelitian}

Metode penelitian yang digunakan dalam penelitian ini menggunakan metode penelitian Kualititatif berdasarkan studi kasus terdiri dari beberapa desain 
penelitian dan subyek penelitian, metode pengumpulan data dan metode analisis data. Dengan memanfaatkan kemampuan artificial intelligence untuk mempelajari beberapa faktor secara bersamaan. Terdapat 3 tahap yang dilakukan dalam penelitian ini. Tahap pertama adalah studi pendahuluan dan pengumpulan data awal. Tahap kedua adalah analisis data awal dan perancangan algoritma optimasi.

Tahap ketiga adalah penerapan algoritma optimasi dan analisis hasil penerapan perlakuan. Terdapat 3 hasil dari penelitian ini. Pertama, terjadi peningkatan jumlah klik dari $7 \mathrm{klik} / \mathrm{hari}$ menjadi $8 \mathrm{klik} / \mathrm{hari}$. Kedua, terjadi penurunan jumlah tayangan dari 129 tayangan/hari menjadi 53 tayangan/hari. Ketiga, terjadi peningkatan Click Through Rate dari 5,43\% menjadi $15,09 \%$. Berdasarkan hasil tersebut menyatakan bahwa penerapan algoritma optimasi yang disusun mampu meningkatkan efektivitas pemasaran digital (Hadi et al., 2019).

\subsection{Desain Penelitian dan Subyek Penelitian}

Penelitian ini merupakan penelitian deskriptif observasional pada UMKM di Indonesia menggunakan metode triangulasi yang menggabungkan metode wawancara terstruktur, wawancara mendalam dan observasi terhadap UMKM dan media sosial yang digunakan. Subyek dalam penelitian ini adalah UMKM yang dipilih secara purposive sampling.

Subyek dipilih sesuai dengan kriteria:

a) UMKM berbagai produk baik yang memiliki produk, reseller maupun dropshiper.

b) Pernah dan sedang menggunakan media sosial dalam komunikasi usahanya, bersedia menjadi subyek penelitian. Sebaran wilayah subyek yang direkrut dalam penelitian dari seluruh Indonesia dengan berbagai ragam profesi namun sebagai UMKM.

\section{Metode Pengumpulan Data}

Penelitian ini menggunakan data primer yang diperoleh berdasarkan wawancara terstruktur dan wawancara jarak jauh menggunakan sebaran questioner. Data yang diperoleh meliputi data karakteristik umum, data penggunaan sosial media dalam UMKM, termasuk tujuan, manfaat dan hambatan yang dihadapi.

Data dilengkapi dengan hasil observasi peneliti pada UMKM dan media sosial yang digunakan. Analisis Data yang diperoleh, dianalisis menggunakan statistik deskriptif dan analisis kualitatif. Tipe penelitian menggunakan observasi alami (natural observation). Cakupan penelitian seluruh wilayah Indonesia ini dilakukan karena peneliti yakin sebaran instrumen penelitian dapat menjangkau seluruh wilayah tanpa harus bertatap muka langsung. Instrumen penelitian yang digunakan Wawancara, Pengamatan/Observasi dan Dokumentasi. Prosedur penelitian yang dilakukan belalui 3 tahap yakni tahapan deskripsi atau tahap orientasi, tahap reduksi dan tahap seleksi. Adapun Analisis data menggunakan secara triangulasi (gabungan)

\section{Hasil}

Pada pertemuan Training Of Trainer Program Pengembangan Wirausaha Bisnis untuk mewujudkan superconnection Madein ITB dan Holding Company 
alumni ITB dan Jaringannya menurut Hanung Harimba, Bidang Deputi Usaha Kecil dan Menengah Kementerian Koperasi dan UMKM.

Keterlibatan wirausaha bisnis pada dua generasi yang saat ini eksist, Generasi Z sebanyak $27 \%$ sedangkan Milenial $73 \%$ hal ini merupakan tantangan bagi kita mengembangkan sektor yang inovatif selain itu jumlah UMKM micro milenial sebagian bukan sektor formal, ini disebabkan karena mereka tidak terserap pada sektor formal. Program kewirausahaan hampir $90 \%$ mereka ditanya apakah ingin mengembangkaan wirausaha kurang dari 3,5\% lebih rendah di banding Thailan, Malaysia dan Singapura.

Oleh karenanya hasil survey bahwa ketika para UMKM ini diajukan pertanyaan apakah mereka ingin mengembangkan usahanya tingkat minatnya stagnan artinya tidak ada minat untuk mengembangkan lebih jauh. Ini dikarenakan bahwa umkm ini merupakan peralihan ketika sektor formal sudah tidak ada peluang hanya peruntukan penghasillannya hanya untuk pemenuhan kehidupan harian.

Namun begitu mereka mempunyai visi future yang berbasis teknologi dan kreatifitas. Pemerintah melihat hal ini Jumlahnya harus diperbanyak khususnya dari kelompok terdidikterlebih pada saat memasarkan produk yang sudah menggunakan media sosial dan digital, memerlukan strategi khusus agar tidak hanya sekedar pandai memproduksi namun juga memahami dan menguasai sosial media marketing.

Pengimplementasian media sosial pada UKM memberikan manfaat di antaranyasebagai galeri produk, mendata kebutuhan supplier, mendata kebutuhan distributor, survey target konsumen,dan memantau konsumen. Di samping itu media sosial juga bermanfaat sebagai forum diskusi, membantu pengambilan keputusan, memberikan respon pada konsumen, mendata kebutuhan konsumen, sebagai media pemasaran dan iklan, dan sebagai saran kontak personal dengan konsumen.(Purwidiantoro et al., 2016)

Pada sosial media marketing ini Peneliti menggunakan aplikasi pesan whatsapp sebagai aplikasi ending untuk berinteraksi sekaligus memberikan edukasi. Namun aplikasi yang digunakan tidak bisa berdiri sendiri harus di topang dengan aplikasi media sosial yang lain yaitu facebook/Instagram. Alasannya saat ini pengguna facebook setiap hari meningkat begitupun pengguna whatsapp dan pergerakan ekonomi UMKM mampu dijembatani oleh ketiga aplikasi sosial media ini.

Strategi pengembangan kompetensi UKM di jaman digital saat ini banyak sekali metode yang dapat di tempuh yang akan di jabarkan dalam sub bahasan berikut: Strategi Membangun Traffic dan Konversi, Program Weekly Sharing Sesion, Menyelenggarakan Kelas 100 Orderan, Kelas Whatsapp Marketing, Kelas Copywriting Instan Memengaruhi Pembaca Iklan. 


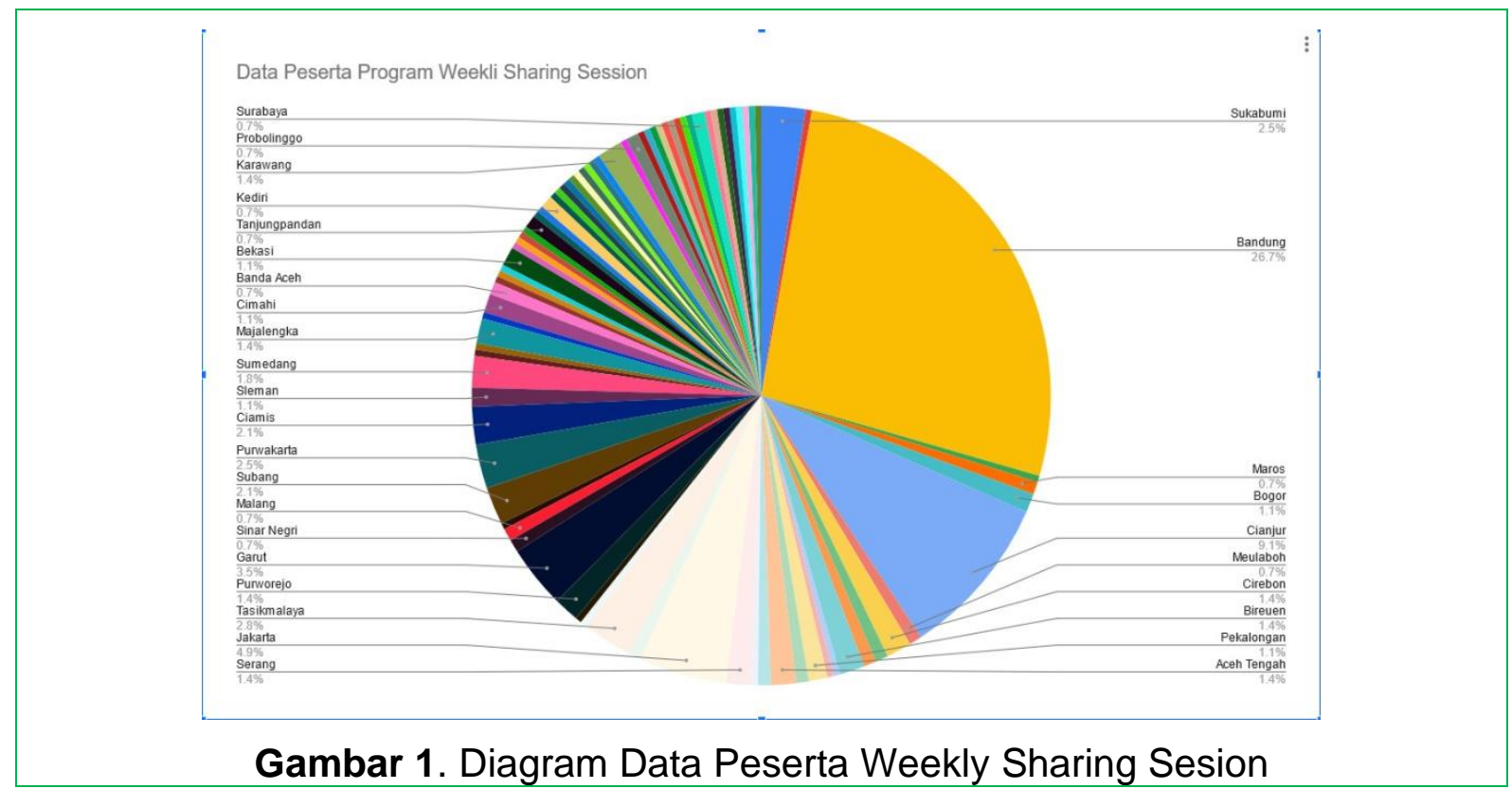

Pada Program Weekly Sharing Sesion ini, Peneliti menggunakan aplikasi whatsapp blaster untuk mengirim pesan ke ribuan kontak whatsapp secara personal, sehingga tidak digabungkan dalam satu grup. Dikirim secara personal karena kemungkinan untuk dibaca dan direspon oleh para UMKM sangat tinggi, lain halnya jika di dalam grup, respon akan sedikit lambat. Pesan yang dikirimkan berupa pesan edukasi tentang digital marketing. Dijadwalkan setiap hari selasa dan kamis malam pukul 19.30 s.d. 21.00 Wib. Adapun respon dari para UMKM yang mendapat weekly sharing sesion ini ada pada testimoni di gambar 6 . Peserta yang berpartisipasi dari seluruh Indonesia seperti yang tercantum pada diagram diatas.

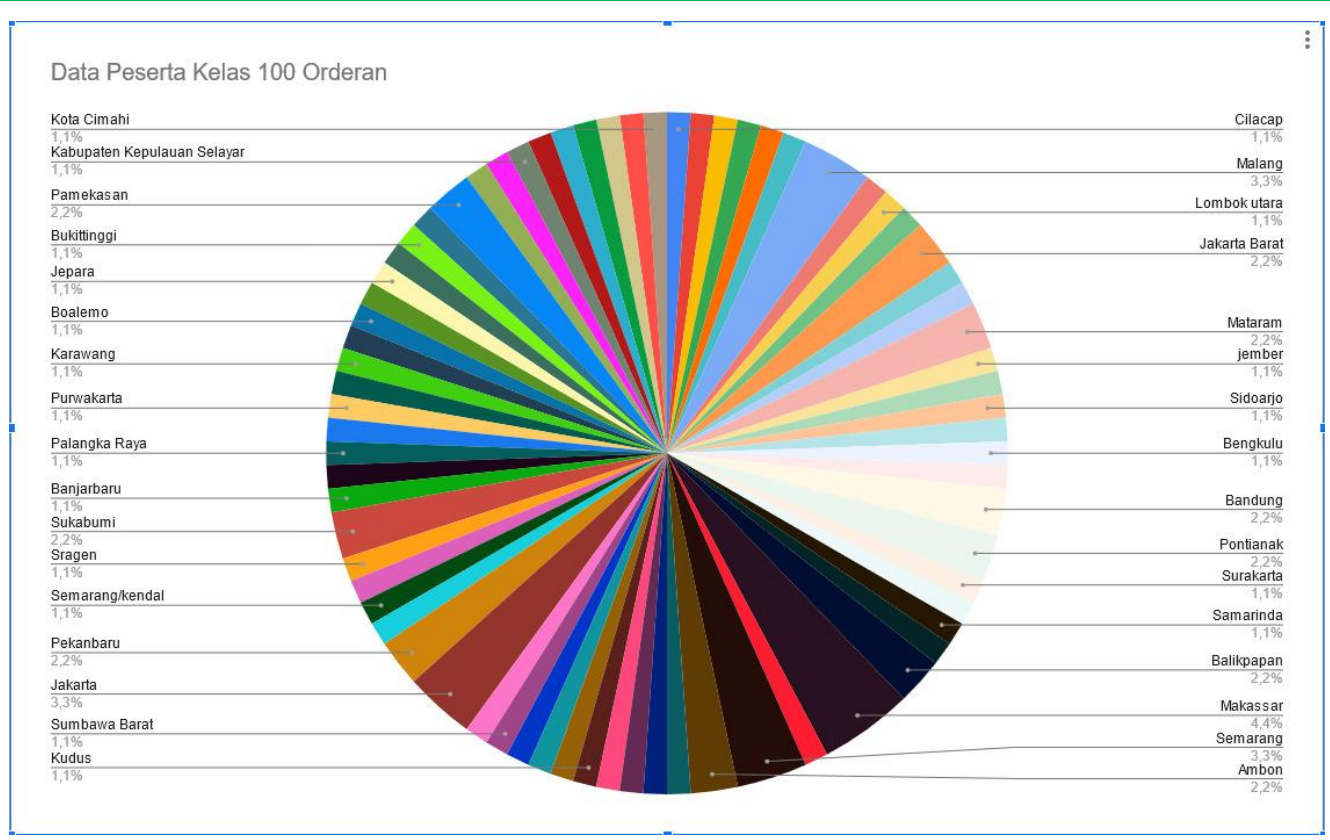

Gambar 2. Diagram Data Peserta Kelas 100 Orderan 


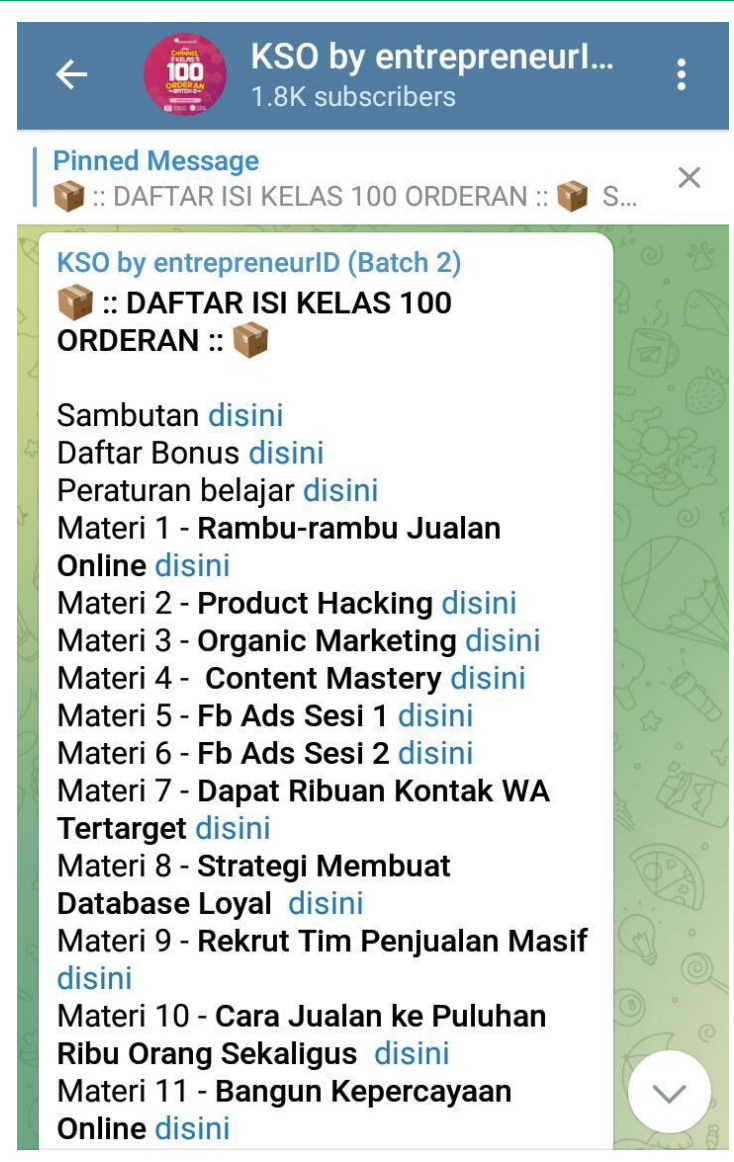

Gambar 3. Grup Telegram Kelas 100 Orderan

Mekanisme pemberian pelatihan UMKM pada Kelas 100 Orderan melalui grup Telegram karena dapat menampung peserta sampai ribuan. Kelas 100 Orderan ini berlangsung per 2 minggu, karena materi di share setiap hari sampai UMKM mempraktikannya. Antusias peserta dapat terlihat dari jumlah anggota grup sebanyak 1800 ribuan orang, dari berbagai kota di Indonesia seperti yang tertera pada diagram gambar 2.

Pada Kelas Whatsapp marketingpun, mekanismenya sama seperti Kelas 100 Orderan, materi disampaikan melalui Telegram dengan alasan daya tampung sampai 4,9 ratusan orang. 


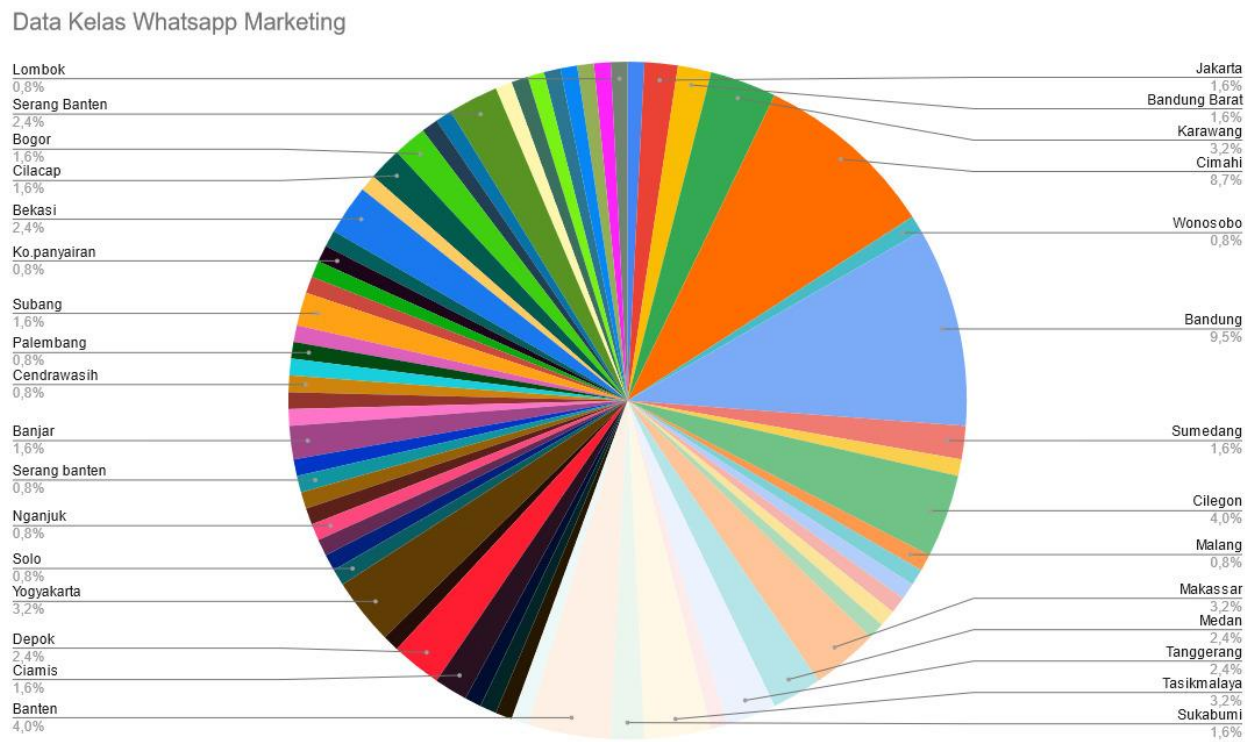

Gambar 4. Diagram Data Peserta Kelas Whatsapp Marketing

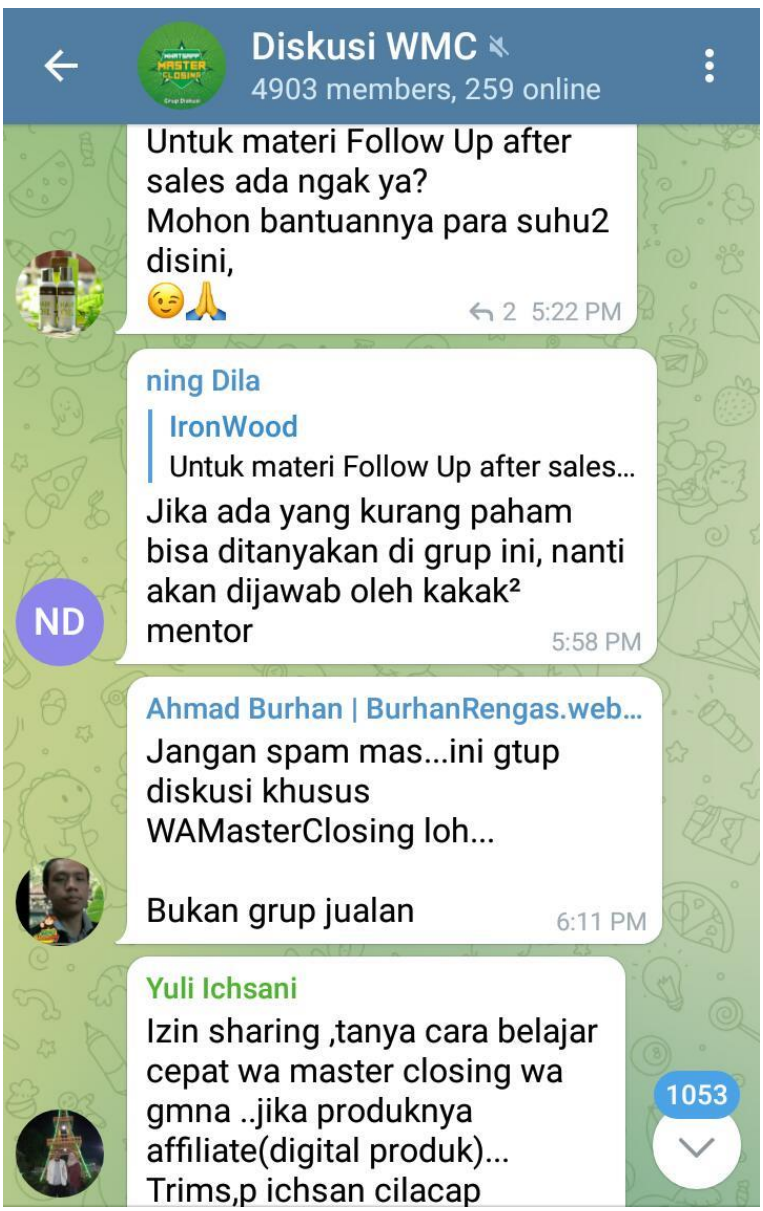

Gambar 5. Grup Telegram Whatsapp Marketing 
Pada Kelas Online Copywriting mekanismenya seperti kelas yang lain, materi disampaikan melalui Telegram diikuti 923 orang. Perbedaan kelas ini dengan kelas yang lain terletak pada pelatihan yang diberikan, pelatihan dan penugasan pembuatan copywriting iklan membutuhkan waktu lama untuk kroscek satu persatu. Hasil penulisan copywriting peserta dikoreksi dan melihat pola-pola copywriting yang dapat memengaruhi calon pembeli. Namun mekasnime ini di ambil secara acak karena peneliti tidak memungkinkan untuk mengecek satu persatu maka setiap harinya di ambil hasil copywriting 10 peserta untuk di ulas dan di koreksi.

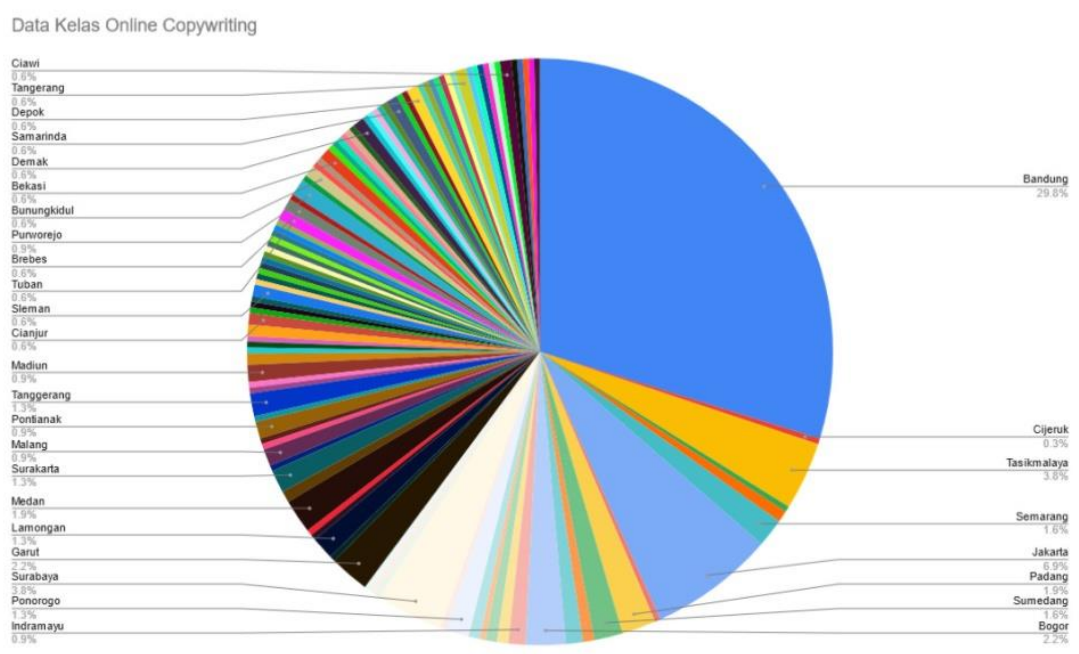

Gambar 6. Data Peserta Kelas Online Copywriting

KOC by entrepreneu...
923 subscribers
Samned Message \#1
KOC by entrepreneurID (Batch 4)
Halo Peserta Alumni KOC by
entrepreneurID Batch 4
Kalau tidak ada halangan, insyaAllah
besok akan dimulai program ini.
Ini program belajar terbaru kami
namanya
"Bisnis dari Nol sampai
Menghasilkan"
Isinya membahas cara membangun
bisnis dari awal sampai cuan
(untung).
Selain itu juga membahas apa saja
yang harus dihindari agar bisnis
bisnis besar.
Program ini gratis, karena kami niat
membantu teman-teman yang butuh
ilmunya (4)
Jika dirincikan dengan detail, mereka

Gambar 7. Grup Telegram Kelas Online Copywriting 


\section{Pembahasan}

\subsection{Strategi Membangun Traffic dan Konversi}

Strategi yang harus dimiliki UMKM dalam memasuki digital marketing yang pertama adalah dengan membangun Traffic yang nantinya akan dikonversi menjadi penjualan. Berikut tahapan dasar yang peneliti lakukan. Dimulai dari membuat lead magnet yang merupakan awal dari perjalanan rekruitmen pengumpulan database yang didapatkan dari sosial media yang merupakan marketing secara organic (Facebook). Lead magnet berfungsi sebagai pemancing para UMKM dalam mengumpulkan database, hal ini pun dilakukan oleh peneliti dengan cara menyebar lead magnet agar mendapat nomor kontak whatsapp dengan cara mengundang mereka melalui event kuliah whatsapp, free ebook, belajar bersama selama 3 hari dan lead magnet lainnya dengan cara posting event yang akan diselenggarakan di grup-grup Facebook tertarget yang diarahkan ke nomer whatsapp peneliti.

Sementara sebaran lead magnet terus dilakukan ketika event kuliah whatsapp selesai dan mendapat data base baru di lanjutkan Program Weekly Sharing Sesion. Program ini berlangsung menghimpun UMKM dengan cara sebaran informasi dan teknik penjualan, dilaksanakan seminggu 2 (dua kali) menggunakan media aplikasi pesan whatsapp.

Jam performa pengiriman edukasi penjualan disarankan antara pukul 18.0021.00 wib. Informasi edukasi tentang cara berjualan online ini mendapat antusias yang sangat responsif dari $80-90 \%$ penjualan online. Ini terbukti dengan banyaknya testimoni setelah sebaran edukasi di lakukan.

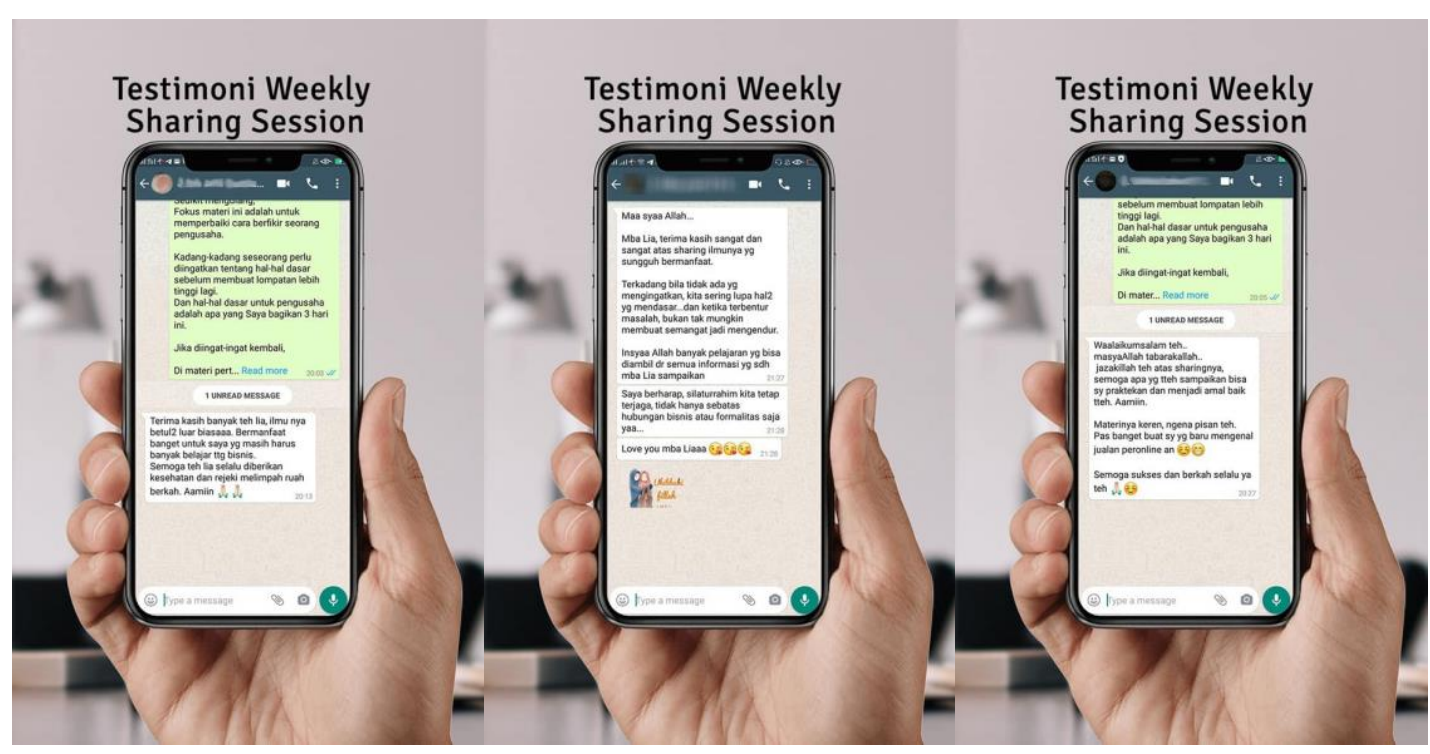

Gambar 8. Testimoni Hasil Pelatihan Kompetensi Digital Marketing UMKM

Pada tahap edukasi ini, jika produk UMKM berbeda dapat melakukan hal yang sama dengan konten edukasi yang disesuaikan hal ini dilakukan untuk membangun engagement sehingga memudahkan dalam membangun trust kemudian akan dikonversi menjadi prospek saat menjual produk. 
Pilihan lain saat rekruitmen dan menambah data base kontak adalah dengan, program BC Series, atau Broadcast Series ini merupakan program lead magnet mengumpulkan database whatsapp dari facebook. $B C$ Series ini bertujuan memberikan manfaat terlebih dahulu pada sasaran. $B C$ series berisi 6 (Enam) materi yang sudah di siapkan terlebih dahulu tentang teknik digital marketing (cara jualan online) yang disebarkan selama 3 (tiga) hari berturut-turut, sehari 2 kali pagi dan malam.

Contoh lead magnetnya sebagai berikut :

"Tau gak?

Facebook adalah salah satu sosial media yang dipakai banyak orang.

Di Indonesia, pengguna Fb sudah tembus 130 juta orang lebih".

Dengan pengguna sebanyak itu, membuat Facebook jadi media promosi yang sangat potensial.

Tapi masalahnya, ternyata masih ada juga yang belum memahami cara memasarkan produknya lewat Facebook. Setiap promosi di Facebook

- Yang like jarang

- Yang komen gak ada

- Apalagi yang beli.

(Sepi... )

Untuk membuat Facebook menjadi media promosi yang luar biasa. Memang gak bisa sembarangan.

Ada ilmunya, ada strateginya. Namanya "Facebook Marketing" (-)

Nah, lalu apa inti status ini?

"Untuk yang pakai Facebooknya buat jualan, Saya punya materi yang bisa membantu. Harapan Saya setelah praktik ilmunya nanti, pesertanya jadi mudah dapat pembeli, minimal paham cara promosi di Facebook. Jadi, lewat postingan ini Saya mengundang siapa saja yang baca status ini untuk ikut belajar bersama dengan tema: "BELAJAR FACEBOOK ORGANIC"

Mereka yang akan ikut program ini akan belajar:

- 3 hal yang harus dipahami sebelum jualan di Facebook

- Cara menemukan calon pembeli ideal di Facebook

- Tips untuk membuat orang lain mau like, komen, bahkan Share postingan kita

- Strategi menghasilkan income dari facebook organic

- Tips Genjot Omzet lewat Facebook, dan

- Pola Jualan Laris Manis di Facebook

Goal programnya adalah agar pesertanya nanti menguasai step demi step dapat pembeli lewat Facebook. Jika Anda jualan di Facebook, maka silahkan ikutan.

Gratis koq, cukup ikuti cara daftar dibawah ini 
1. Mention 3 teman yang juga jualan di $F b$.

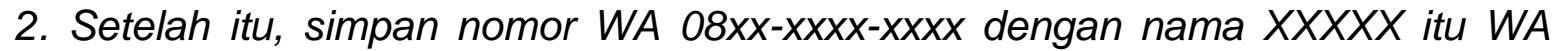
Saya. . :)

3. Konfirmasi pendaftarannya dengan chat ke WA tersebut formatnya "Belajar Jualan di Fb-Nama Anda"

Gimana, gampang kan? (-)

Oh ya, sebelum ikut belajar,

Saya ingin sampaikan bahwa pendaftaran program ini akan diyutup tiba-tiba, dan ketika status ini hilang, artinya pendaftaran sudah ditutup. Karena itu, jika masih bisa baca status nya, jangan sampai melewatkan kesempatan spesial ini ya.

Cukup

1. Mention 3 teman

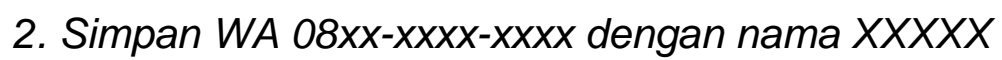

3. Chat WA tersebut formatnya "Belajar Fb_Nama Anda"

Selamat daftar dan sampai ketemu di materi nanti.

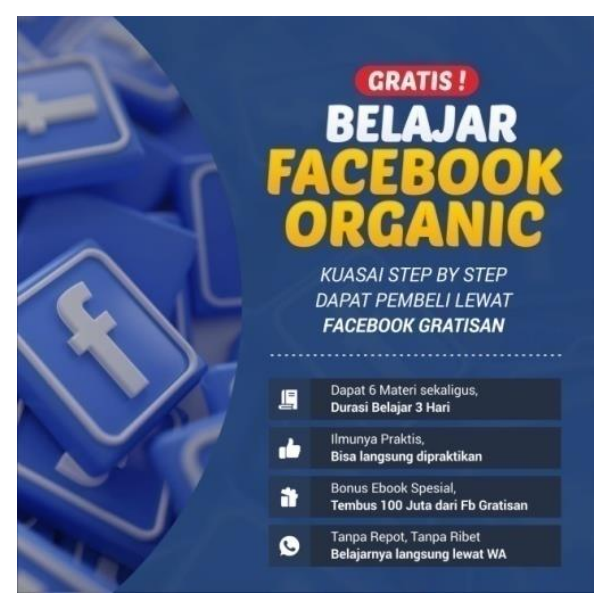

Gambar 9. e-Flyer Event Kuliah Whatsapp untuk UMKM

Respon dari event ini : 


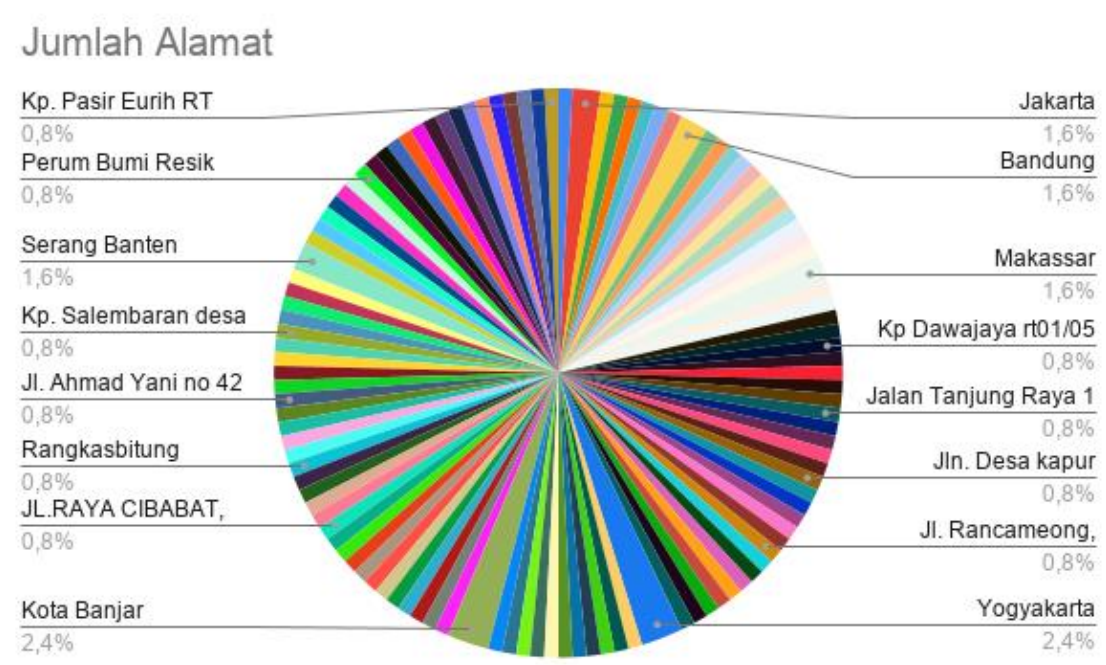

Gambar 10. Diagram Responses Event Kuliah Whatsapp untuk UMKM

Setelah database terkumpul, engagement terbangun dan trust mulai di dapatkan dari para UMKM yang sudah terjaring dari Facebook, Peneliti melanjutkan program strategi pengembangan UMKM dengan menyelenggarakan Kelas 100 Orderan, yang berafiliasi dengan entrepreneur ID.

Meskipun demikian penjualan online membutuhkan trik dan cara tertentu, disertai dengan konsistensi tinggi karena hal ini akan berimbas pada penghasilan. Melihat potensi yang sangat besar seharusnya mudah mendapatkan konsumen tapi faktanya tidak semudah itu.

Terdapat aturan main yang wajib dilakukan saat melakukan penjualan online atau digital marketing, kategori ini bisa dikatakan hal-hal yang harus dilakukan secara runut apabila tidak dilakukan maka kegiatan posting iklan di internet akan menjadi sia-sia.

Hal tersebut menunjukkan bahwa jualan online di internet itu memiliki pola agar mudah mendapatkan calon customer. Hal ini menjadi jawaban kenapa selama ini para UMKM kesulitan mendapat pembeli di internet. Jika ingin penjualannya meningkat maka memerlukan pola secara berurut. Dengan mempraktikan pola tersebut secara berurut maka akan menmebus orderan yang datang secara rutin, pala tersebut adalah pola Traffic dan pola Konversi.

Traffic adalah Lalu lintas calon pembeli potensial yang mengunjungi toko online/website UMKM. Sedangkan konversi yakni kegiatan mengubah lalu lintas calon pembeli yang sudah terekap dalam data untuk kemudian di prospek kembali supaya terjadi transaksi penjulan dan pembelian. Sederhananya, jualan online itu prosesnya ada calon pembelinya terlebih dahulu setelah itu bisa dapat pembeli. Yang dilakukan selama ini oleh para UMKM yang beralih dari offline ke online adalah dengan melakukan spamming, atau mengirimkan gambar produk dan tulisan iklan tanpa mengenalkan identitas dirinya dan hal ini bahkan akan membuat calon customer risih.

Jika masih melakukan hal tersebut bukan tidak mungkin mendapat customer tapi tidak akan pernah loyal, karena calon customer tidak datang dengan ikhlas 
sesuai kebutuhan mereka. Bisa saja mendapat beberapa pembeli namun itu hanya bersifat tentatif.

Dari hasil traffic atau lalulintas pengunjung yang banyak maka akan memungkinkan potensi penjualan akan meningkat dan menurut peneitian sebelumnya strategi ini dipilih bukan hanya karena biayanya yang lebih terjangkau bagi pelaku UMKM, akan tetapi berdampak pada jaringannya yang lebih luas dan dapat menjangkau segmen konsumen yang lebih beragam (Hapsoro et al., 2019).

\subsection{Kulwa Strategi Reseller Punya Penghasilan Tetap}

Sistem reseller adalah model bisnis yang sangat potensial untuk siapapun. Tanpa perlu susah payah buat produk atau riset produk, teman-teman reseller sudah bisa berbisnis dan mendapat income darisana dengan resiko yang sangat kecil. Yang perlu dilakukan seorang reseller yaitu mempertemukan produk dengan pembelinya. Kalau konsumen dan produk sudah bertemu, itu yang menjadi penyebab seorang reseller menghasilkan. Dari gambaran tersebut dapat disimpulkan jika ingin penghasilannya lancar, maka UMKM reseller harus mempunyai akses ke penyedia produk dan ke calon pembelinya. Masalahnya,

Mayoritas reseller hanya bisa salah satunya saja. Mereka punya kases ke penyedia produk, tapi mereka tidak punya akses ke calon pembelinya. Akhirnya, setelah punya produk untuk dijual, banyak reseller yang bingung mau jualan produknya kemana dan pada siapa. Karena bingung, akhirnya banyak reseller yang jualannya hanya posting. Posting di status FB, WA, IG. Jualan hanya berfokus ke orang-orang terdekat. Cara ini terkadang berhasil namun banyak juga yang tidak berhasil. Solusinya adalah setiap reseller harus punya sumber calon pembeli mandiri, Salah satu cara yang paling ampuh adalah dengan memiliki database. Database adalah kontak calon pembeli yang bisa dihubungi setiap saat.

Contohnya seperti kontak WA. Bayangkan kalau para reseller punya banyak kontak WA calon pembelinya? Begitu mau promosi atau menawarkan produk baru, tinggal menghubungi database yang ada, maka akan mudah mendapat pembeli..

Hal tersebut yang menyebabkan banyak reseller gagal, karena tidak mengetahui secara jelas target pasar yang akan dituju. Dengan adanya database ataupun kontak WA calon pembeli, maka untuk mendapatkan pembeli bukan hal yang sulit. Ada 4 langkah yang perlu dilakukan untuk mendapat banyak kontak calon pembeli:

1) Membuat umpan

2) Tawarkan ke target pasar

3) Whitelist kontak baru

4) Menyapa database tersebut.

\subsection{Copywriting Instan, Memengaruhi Pembaca Iklan}

Saat memasarkan sesuatu, setiap orang tidak mau iklannya diabaikan, dan diacuhkan. Agar tidak seperti itu maka sebisa mungkin membuat iklan yang bisa mempengaruhi pembacanya. Faktanya jika ada yang merasa hasil penjualannya kecil, yang respon iklannya sedikit, dan jauh dari target, bisa saja itu karena iklannya kurang mempengaruhi. Iklan yang biasa, membuat pembacanya tidak tergerak untuk melakukan sesuatu setelah membaca iklannya. Teknik Influence 
copywriting artinya adalah cara menulis iklan yang bisa mempengaruhi pembacanya.

Semua ada ilmunya, ada caranya, ada polanya. Termasuk membuat orang lain terpengaruh dengan iklan, cara membuat iklan yang mempengaruhi itu adalah di kalimat pembuka iklan.

Beberapa kalimat pembuka iklan adalah kunci membuat pembaca terpengaruh. Kalau bagian ini berhasil, maka pembaca akan tenggelam dalam iklan yang dibuat, dan menerima informasi yang diberikan kepada mereka. Tapi kalau bagian ini dibuat secara asal jadi, maka pembaca akan mengabaikan iklan yang kita tampilkan, dan yang terburuk adalah mereka tidak akan membacanya.

Iklan yang awalnya dibuka langsung dengan penawaran. Akan mendapatkan respon negatif, dan langsung ada penolakan dari dalam diri. Hal tersebut terjadi pada semua orang. Jika pembuka iklannya langsung menawarkan jualan, pasti iklannya akan diabaikan.

Karena itu, mulai sekarang jangan membuka iklan dengan penawaran langsung. Kecuali, Anda yakin kalau yang ditawarkan adalah sesuatu yang dibutuhkan calon pembelinya, sampai-sampai mereka akan sulit tidur kalau tidak membeli produknya. Dan kalau penawaran Anda tidak memberikan perasaan itu, maka berhati-hati di bagian pembuka iklannya.Harusnya bagian pembuka iklan harus bisa membuat pembacanya trance.

Trance adalah kondisi alami dimana perhatian seseorang terserap pada aktivitas yang dikerjakannya dan cenderung mengabaikan lingkungan sekitar. Kalau dihubungkan dengan iklan, maka trance adalah kondisi dimana pembaca fokus dan memberikan perhatian penuh kepada apa yang sedang dibaca.

Kalimat-kalimat pembuka iklan, punya tujuan membuat pembacanya fokus ke iklan yang dibuat. Kalau kalimat pembuka tidak bisa membuat pembacanya fokus, maka iklan tersebut akan cenderung diabaikan, penawarannya akan ditolak, dan hasilnya tidak akan maksimal. Alasan kenapa penawaran sering tertolak adalah bisa jadi pembaca tidak sedang dalam kondisi trance saat menerima penawaran tersebut.

Sebaliknya, begitu pembaca fokus, maka mereka akan menyimak pesan yang terkandung dalam iklan tersebut dan pada akhirnya akan mudah diarahkan untuk membeli. Bukalah Iklan dengan kalimat yang membuat pembacanya fokus ke Isi iklannya. Jadi, ada banyak cara membuat pembaca trance, mulai dari copywriting iklan dengan salah satu dari 5 cara berikut yaitu,
a) TranceWords
b) YesSet
c) Story
d) Break thePattern
e) Pacing

\section{Teknik 1: Trance Words}

Karena tujuannya membuat pembaca trance, maka gunakan kata-kata untuk mengaktifkan kondisi trance atau bisa juga disebut trance words. Contoh-contoh 
Trance Words: bayangkan, pikirkan, imajinasikan, ingat, rasakan, tahu, sadar, paham.

Kata-kata tersebut akan membuat pembaca memasuki dunia internalnya. Cara mempraktiknya adalah tinggal menysipkan kata-kata Trance Words kedalam kalimat- kalimat pembuka iklan. Kalau dipakai dalam dunia iklan, contoh penerapannya seperti berikut:

1. Bayangkan kondisi dimana Anda mampukeluar dari masalah- masalah Anda saat ini!

2. Pernah kepikiran gak tentang cara meningkatkan produktivitas secaracepat?

3. Sebelum baca pesan ini sampai selesai,coba ingat-ingat kembali.

Kata yang di cetak tebal adalah trance wordsnya. Begitu kata itu ada di kalimat-kalimat pembuka iklan, maka itu bisa membuat pembacanya trance. Setelah kalimat pembuka yang ada Trance Wordsnya, maka bisa dilaanjutkan dengan beriklan.

\section{Teknik 2 - Yes Set}

Teknik yang ini cukup mudah yaitu membuka iklan dengan sesuatu yang membuat pembaca mengangguk setuju. Sesuatu itu bisa pertanyaan, bisa pernyataan. Kalau pertanyaan, maka buka iklan dengan pertanyaan yang mutlak jawabannya "YA".

Tipsnya, buatlah pembaca mengatakan "YA" minimal 3 kali. Ketika mereka menjawab "YA" berkali-kali itu namanya adalah Yes Set. Dan ketika kondisi yes set terjadi, maka orang itu jadi mudah untuk dipengaruhi. Contoh penerapannya seperti berikut,

Kira-kira apa jawaban dari pertanyaan-pertanyaan diatas? Jawabannya adalah:

"Sebelum Andamendapat informasi bermanfaat dari pesan ini, silahkan jawab dulu beberapa pertanyaan berikut secara jujur":

a. ApakahAndainginmemilikipenghasilanlebihbanyakdari yangAndamilikisaatini?

b. ApakahAndainginmerasaamansecarakeuangan?

c. ApakahAndainginhiduptenangtanpaharusmerasakan kondisiekonomiyangmepetsaatakhirbulan?

.Jika sudah jawaban meraka adalah "YA" berkali- kali, maka kita bisa melanjutkan iklannya, lakukan hal yang sama saat melakukan iklan. Buat pembaca setuju berkali-kali dengan pertanyaan Anda. Selain pertanyaan, kita bisa juga membuat pembaca secara spontan menjawab "YA" dengan pernyataan Yes Set.

Cara yang dilakukan adalah dengan memberikan statement di awal iklan atau pernyataan yang membuat pembaca mengangguk setuju. Jika semakin banyak statement yang membuat pembaca setuju, maka nantinya akan mudah memberikan informasi tambahan kepada mereka.

\section{Teknik 3 - Story}


Teknik story merupakan Teknik iklan yang dimulai dengan cerita. Karena sejak kecil orang Indonesia suka mendengarkan dongen, itu terbawa sampai mereka dewasa. Saat dewasa, kita lebih mudah diajak komunikasi dengan cerita. Gunakan itu sebagai pembuka iklan, agar iklan tersebut membuat pembacanya trance.

Cara mempraktikan teknik ini mudah. Intinya adalah menceritakan sesuatu ke target pasar.

Contohnya, kita bisa menuliskan ini

1. Jadi ceritanya kemarin ada kejadian seru saat Kami jalan-jalan di Mall.Ceritanya begini..

2. 1 Tahun yang lalu,Kami lupa tepatnya bulan apa.Kami mengalami kejadian yang luar biasa.

Ini cerita tentang bagaimana seseorang bisa..

Dan cerita-cerita lainnya.Tips tambahan agar teknik ini berhasil, pastikan ceritanya ada hubungannya dengan tujuan iklan. Misal lagi menawarkan produk,artinya ceritanya berhubungan dengan produk. Karena jika tidak sejalan antara cerita dan tujuan, maka pembaca hanya menikmati tulisan tanpa melakukan apapun.

\section{Teknik 4 - Break The Pattern}

Konsepnya adalah kita melakukan "sesuatu diluar kebiasaan umum" agar orang lain bingung, nah ketika mereka bingung, maka kita akan mudah menyusupi mereka dengan informasi dari kita. Seperti namanya break berarti menghancurkan dan the pattern berarti pola $\mathrm{Ya}$, intinya kita membuat orang lain bingung dengan apa yang kita lakukan sebagai pembuka komunikasi.

Kalau diterapkan dalam iklan seperti apa contohnya? Di iklan, kita perlu menuliskan hal yang "tidak biasa" sebagai kalimat pembuka. Nah, Ketika pembaca bingung atau kaget dengan yang Anda tuliskan, maka saat itu mereka sedang membuka lebar-lebar gerbang untuk menerima informasi selanjutnya.

Contohnya seperti ini

1. Mana yang benar?Suami yang kelola uang atau istri yang kelola uang?

2. Ingat gak apa yang special ditanggalini?

3. Kalau ada yang bilang Sapi kakinya 2,pasti dia salah

Ya, buat bingung atau buat kaget pembacanya, Setelah pembaca bingung atau kaget, lanjutkan iklan dengan informasi yang ingin Anda berikan.

\section{Teknik 5 - Pacing}

Pacing adalah menyelaraskan kondisi target pasar. Jadi, tugas kita adalah memikirkan kondisi yang sedang dialami target pasar saat ini, lalu beritahu mereka bahwa ada orang lain yang merasakan hal yang sama. dengan cara ini maka pembaca akan lebih respect dengan iklan kita karena mereka merasa punya teman yang merasakan hal yang sama. Dengan begitu, akhirnya mereka jadi trance. 
Kondisi yang dialami target pasar ini bisa masalah, bisa kebutuhan, bisakeinginan,ataukondisiapapun.Danorangyangditonjolkanbisa diri kita sendiri, kenalan kita, atau konsumen kita sebelumnya, bahkan tokoh dari cerita yang pernah kitadengar.

Contoh pembuka iklannya seperti ini

1. Kalau ada yang punya masalah gangguan pola menstruasi, itu sama seperti salah satu konsumen kami, Namanya Mba Nita.

2. Tidak banyak yang tau kalua dulu kami pernahpunya masalah dengan mitra bisnis kami.

3. Mayoritas orang yang pernah merasakan alergi akan trauma dengan produk tertentu, dan mungkin Anda juga salah satu yang pernah merasakannya

Angkat kondisi yang sedang dialami oleh target pasar, dan beritahu bahwa ada orang lain yang merasakan hal yang sama seperti mereka. Lalu jadikan itu sebagai pembukaiklan. Jadi begitulah 5 teknik influence copywriting.

1. Trance Words, masukan trance words kedalam kalimat-kalimat pembuka iklanAnda

2. Yes Set, berikan pertanyaan, atau pernyataan yang membuat pembaca setuju

3. Story, buka iklan dengan cerita

4. Break The pattern, tuliskan kalimat yang tidak biasa sebagai pembuka iklan,dan

5. Pacing, buka iklan dengan informasi ke pembaca bahwa ada orang lain yang pernah merasakan kondisi yang sama dengan mereka

Dengan 5 teknik ini, maka iklan Anda akan lebih mempengaruhi Selalu ingat bahwa salah satu kunci keberhasilan iklan terletak dibagian pembukanya. Kalau pembukanya sudah menarik bahkan mempengaruhi, maka itu seperti $50 \%$ keberhasilan iklan. Tapi kalau pembukanya asal-asalan, maka itu akan menghancurkan iklan secara keseluruhan. Jadi, lebih hati-hati lagi ya dalam menulis kalimat-kalimat pertama dari iklan Anda.

Perbedaan penelitian ini dengan beberapa penelitian sebelumnya adalah pada penelitian ini dilengkapi dengan tahapan-tahapan pembinaan untuk meningkatkan kompetensi UMKM secara kontinyu, dan dilengkapi dengan arahan langsung melalui sosial media lengkap dengan praktk-praktik penugasan sehingga UMKM dapat merasakan perubahan peningkatan penghasilan sejak hari pertama mengikuti pelatihan-pelatihan yang peneliti berikan. Karena sesuai dengan tujuan dari penelitian ini adalah untuk meningkatkan kompetensi UMKM di bidang digital marketing.

Dari hasil temuan bahwa sebelum UMKM mengikuti pembinaan pelatihanpelatihan yang peneliti berikan secara signifikan, UMKM masih merasa bingung ketika berjualan menggunakan media sosial, dari mulai pembuatan akun media sosial yang masih bercampur dengan konten-konten pribadi dipilah dan dibuatkan akun baru yang disetting khusus untuk berjualan dengan konten-konten yang sesuai dengan produk dan menentukan target market yang tepat, membuat konten postingan dengan aplikasi canva, posting gambar penawaran produk, mengumpulkan data base/calon customer tertarget sesuai produk mereka masing- 
masing sampai pada arahan closing dan follow up customer hingga terjadinya transaksi baik melalui aplikasi formulir order ataupun melalui aplikasi pesan whatsapp.

Menabung konten postingan yang disimpan di aplikasi telegram agar saat posting setiap harinya tinggal ambil dan upload di media sosial, dalam pelatihan kompetensi UMKM inipun mereka diberikan pemahaman waktu yang tepat untuk posting penawaran iklan yakni dengan menggunakan prinsip minum obat, pagi, siang dan malam merupakan waktu-waktu prime time posting iklan.

Selain itu mereka di sarankan untuk posting digrup-grup tertarget dengan rutin. Setelah merka melakukan selama 3 bulan perkembangan akun mereka mulai terlihat dan menjadikan akun UMKM ini menjadi terkenal daripada akun media sosial sebelumnya karena disebabkan dari rutinitas postingan, konten postingan yang menarik, sharing di grup-grup tertarget dan interaksi di kolom komentar sehingga dapat membangun trust untuk calon customer.

\section{Kesimpulan}

Temuan pokok penelitian minimnya kompetensi UMKM mengenal pemasaran digital, meski mereka sudah mengenal media sosial bisa digunakan untuk memasarkan produknya namun dibutuhkan strategi-strategi teretentu untuk dapat menghasilkan, dan hal ini merupakan satu kendala di tataran UMKM karena tidak diberikan pemahaman dan keterampilan khusus untuk digital marketing. Kurangnya skill, Kontinyuitas dan Konsistensi menjadi kendala utama UMKM

Implikasi penelitian menitikberatkan pada strategi pengembangan kompetensi UMKM dalam memasuki dunia digital di mulai dari hal yang terdekat dan familiar dengan kehidupan mereka. Menggunakan sosial media marketing seperti aplikasi Facebook, Whatsapp, Telegram dan zoom. Facebook dan Whatsapp digunakan untuk menjaring data base, meningkatkan engagement dan membangun trust. Untuk optimasi selanjutnya menggunakan telegram karena mampu menampung ribuan umkm secara bersamaan dan zoom sebagai aplikasi yang digunakan untuk berinteraksi langsung.

Jenis strategi pengembangan kompetensi umkm yang dirancang mulai dari pembuatan traffic, konversi,penambahan data base, teknik menambah income dan penjualan melalui reseller sampai pada teknik penulisan iklan (copywriting) sederhana namun aplikatif dan mudah di terapkan oleh umkm pemula.

Strategi pengembangan kompetensi umkm diatas merupakan upaya untuk membantu para umkm meningkatkan penjualannya melalui strategi digital marketing, hal ini sangat berguna terlebih setelah kita mengalami resesi ekonomi selama hampir 2 tahun dikarenakan Pendemik Covid 19.

Adapun saran yang dapat diberikan oleh peneliti, selalu pelajari hal baru untuk meningkatkan skill dan kompetensi di jaman sekarang, karena setiap perubahannya sangat cepat sekali jika UMKM tidak mampu beradaptasi. Peran peneliti dan pemerintah yang bersinergi akan sangat membantu meningkatkan kompetensi UMKM dengan menyelenggarakan pelatihan-pelatihan berbasis online, selain jangkauannya sangat luas, materi yang disampaikan bisa dipelajari secara berulang hingga hal ini menjadi added value. 


\section{Daftar Pustaka}

Hadi, S., Prabowo, W., Murdiono, A., Hidayat, R., \& Rahayu, W. P. (2019). Digital Marketing Optimization in Artificial Intelligence Era by Applying Consumer Behavior Algorithm. Asian Journal of Entrepreneurship and Family Business, 3(1), 41-48.

Hadiyati, E., , G., \& Arwani, I. (2018). Pelatihan Tata Kelola Pemasaran Produk Berbasis Mobile Marketing Ukm Industri Perak. Jurnal Pengabdian Masyarakat Universitas Merdeka Malang, 3(2). https://doi.org/10.26905/abdimas.v3i2.2590ihan Tata Kelola Pe. Jurnal Pengabdian Masyarakat Universitas Merdeka Malang, 3(2). https://doi.org/10.26905/abdimas.v3i2.2590

Hapsoro, B. B., Palupiningdyah, \& Slamet, A. (2019). Peran Digital Marketing sebagai Upaya Peningkatan Omset. Jurnal Pengabdian Masyarakat, 23(2), 117120.

NAIMAH, R. J., WARDHANA, M. W., HARYANTO, R., \& PEBRIANTO, A. (2020). Penerapan Digital marketing Sebagai Strategi Pemasaran UMKM. Jurnal IMPACT: Implementation and Action, 2(2), 39. https://doi.org/10.31961/impact.v2i2.844

Priambada, S. (2015). Manfaat Penggunaan Media Sosial Pada Usaha Kecil Menengah (Ukm). Seminar Nasional Sistem Informasi Indonesia, November, 2-3.

Purwidiantoro, M. H., Kristanto, D. F., \& Hadi, W. (2016). PENGARUH PENGGUNAAN MEDIA SOSIAL TERHADAP PENGEMBANGAN USAHA KECIL MENENGAH (UKM) | Hari Purwidiantoro | EKA CIDA. Maret, 1(1), 30-39. http://journal.amikomsolo.ac.id/index.php/ekacida/article/view/19/11

Sulaksono, J. (2020). Peranan Digital Marketing Bagi Usaha Mikro, Kecil, Dan Menengah (Umkm) Desa Tales Kabupaten Kediri. Generation Journal, 4(1), 4147. https://doi.org/10.29407/gj.v4i1.13906

Wahyudi, R., Riyanto, A. D., \& Berlilana. (2019). Pelatihan Aplikasi Teknis Pengembangan Online Marketing Bagi Ukm Se-Balingmascakeb. Jurnal Pengabdian Mitra Masyarakat (JPMM) Vol., 1(1), 21-30.

Wardhana, A. (2015). Strategi Digital Marketing dan Implikasinya Pada Keunggulan Bersaing UMK di Indonesia. In Seminar Nasional Keuangan Dan Bisnis IV, April 2015, 327-337. 